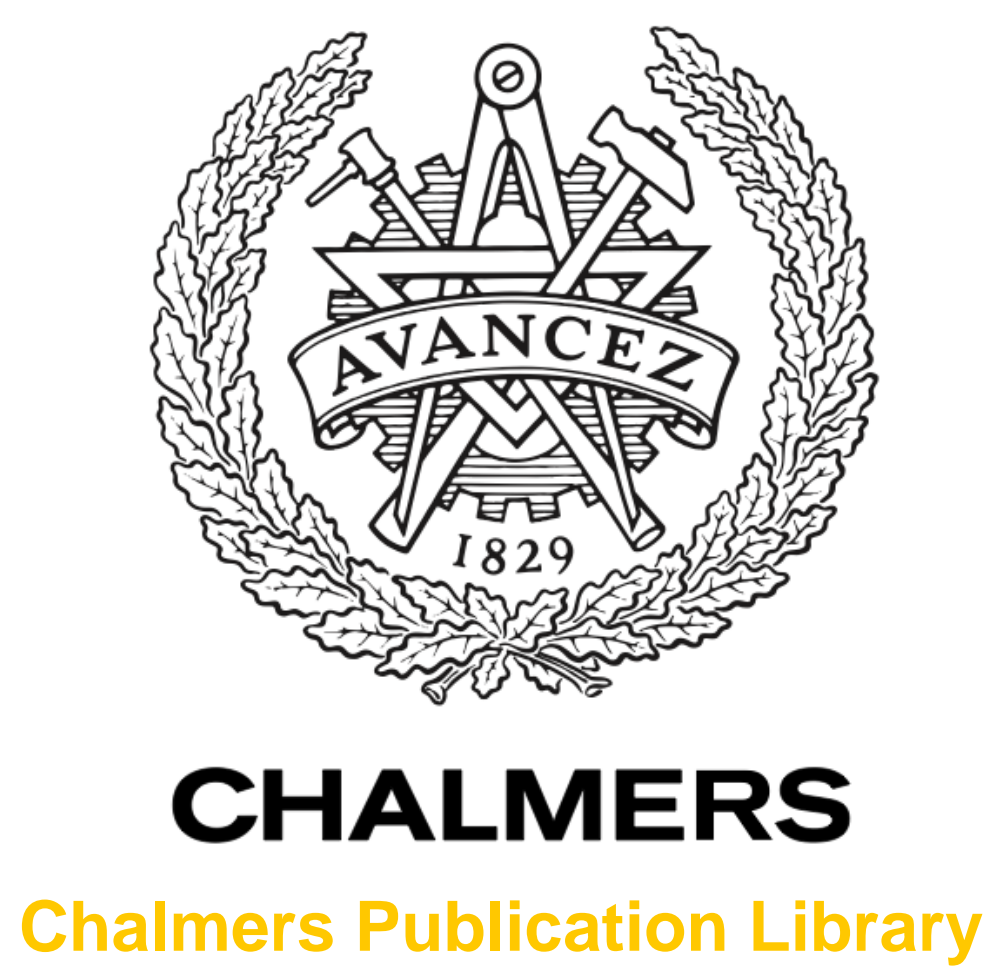

Sewage sludge as a deposit inhibitor when co-fired with high potassium fuels

This document has been downloaded from Chalmers Publication Library (CPL). It is the author's version of a work that was accepted for publication in:

Biomass \& Bioenergy (ISSN: 0961-9534)

Citation for the published paper:

Elled, A. ; Davidsson, K. ; Åmand, L. (2010) "Sewage sludge as a deposit inhibitor when cofired with high potassium fuels". Biomass \& Bioenergy, vol. 34(11), pp. 1546-1554.

http://dx.doi.org/10.1016/j.biombioe.2010.05.003

Downloaded from: http://publications.lib.chalmers.se/publication/126036

Notice: Changes introduced as a result of publishing processes such as copy-editing and formatting may not be reflected in this document. For a definitive version of this work, please refer to the published source. Please note that access to the published version might require a subscription.

Chalmers Publication Library (CPL) offers the possibility of retrieving research publications produced at Chalmers University of Technology. It covers all types of publications: articles, dissertations, licentiate theses, masters theses, conference papers, reports etc. Since 2006 it is the official tool for Chalmers official publication statistics. To ensure that Chalmers research results are disseminated as widely as possible, an Open Access Policy has been adopted.

The CPL service is administrated and maintained by Chalmers Library. 


\title{
Sewage sludge as a deposit inhibitor when co-fired with high potassium fuels
}

\author{
A.L. Elled ${ }^{a, b, *}$, K.O. Davidsson ${ }^{a}$, L.E. Åmand ${ }^{a}$ \\ ${ }^{a}$ Department of Energy and Environment, Chalmers University of Technology, SE-412 96 Göteborg, Sweden \\ ${ }^{\mathrm{b}}$ University College of Borås, SE-50190 Borås, Sweden
}

\section{A R T I C L E I N F O}

\section{Article history:}

Received 26 March 2008

Received in revised form

10 May 2010

Accepted 16 May 2010

Available online 11 June 2010

\section{Keywords:}

Biomass

Stem wood

Wood pellets

Straw pellets

Ammonium sulphates

Kaolin

Zeolites

Municipal sewage sludge

Alkali

Potassium

Deposit formation

Fluidised bed combustion

\begin{abstract}
A B S T R A C T
The objective of this work is to survey the fate of potassium in the gas phase of a fluidised bed boiler and gain deeper understanding of the involved mechanisms during co-firing of municipal sewage sludge with biomass containing high amounts of potassium and chlorine. The results show that formation of alkali chlorides in the flue gas and corrosive deposits on heat transfer surfaces can be controlled by addition of municipal sewage sludge even though the fuel is highly contaminated with chlorine. The beneficial effects are partly due to the content of sulphur in the sludge, partly to the properties of the sludge ash. The sludge ash consists of both crystalline and amorphous phases. It contains silica, aluminium, calcium, iron and phosphorus which all are involved in the capture of potassium.
\end{abstract}

(c) 2010 Elsevier Ltd. All rights reserved.

\section{Introduction}

There is a worldwide interest in biomass combustion for heat and power generation. The major driving force is the fact that biomass is renewable and carbon dioxide neutral [1]. However, some biomass fuels contain high amounts of alkali metal species, i. e. potassium and sodium compounds, which may cause operational problems [2]. Alkali is released from the fuel during combustion. If chlorine is present, it may forms alkali chlorides and deposit on heat transfer surfaces, such as superheater tubes, and cause corrosion [3]. In fluidised bed combustors alkali may also cause costly unscheduled shutdowns since it reacts with silicates in the bed material or in the fuel and forms alkali silicates with low melting temperatures inducing sintering of ash and bed agglomeration [4].

The reference fuel used in this work was a mixture of wood and straw pellets with high amounts of potassium. The

\footnotetext{
* Corresponding author at: University College of Borås, SE-50190 Borås, Sweden. Tel.: +4633 4354644, +46 7021732 84(mobile); fax: +46 33 4354008.

E-mail address: annalena.elled@hb.se (A.L. Elled).

0961-9534/\$ - see front matter (c) 2010 Elsevier Ltd. All rights reserved.

doi:10.1016/j.biombioe.2010.05.003
} 
release of potassium from fuels [5-7] and measures to prevent formation of $\mathrm{KCl}$ in the flue gas has been examined in several studies [8-18]. Addition of municipal sewage sludge is an alternative method to sequestrate potassium and obtain good combustion conditions. Sludge is cheap, needs to be disposed of and is usually produced in the same area as where the power plant is located. Effects observed during co-firing of municipal sewage sludge, such as decreased $\mathrm{KCl}$ concentration in the flue gas and reduced deposit formation, have previously been reported [19,20]; still the cause of the favourable result remains unclear.

The objective of this work was to investigate the fate of potassium and gain deeper understanding of the ash-potassium reaction mechanisms involved during co-firing of municipal sewage sludge and biomass with high content of alkali and chlorine.

\section{Potassium sequestration}

Potassium is essential for plant growth and found in biomass at various concentrations. Owing to its occurrence, it can be more or less volatile during combustion [21]. It is partly released from the fuel, predominantly as chlorides and hydroxides [5-7]. Once released, it is easily available for chemical reaction with other components. Access of sulphur reduces the formation of $\mathrm{KCl}$ in the flue gas since it can react with potassium by reaction 1 .

$2 \mathrm{KCl}+\mathrm{SO}_{2}+\frac{1}{2} \mathrm{O}_{2}+\mathrm{H}_{2} \mathrm{O} \leftrightarrow \mathrm{K}_{2} \mathrm{SO}_{4}+2 \mathrm{HCl}$

The sulphation mechanism has been focus of interest for both experimental and theoretical investigations. There is a general understanding that the sulphation rate in the gas phase is fast at combustion conditions and that the rate limiting reaction is the oxidation of $\mathrm{SO}_{2}$ to $\mathrm{SO}_{3}$ $[8,22,23]$.

Potassium can also be removed from the gas phase by adding a solid sorbent. Kaolin $\left(\mathrm{Al}_{2} \mathrm{O}_{3} \cdot 2 \mathrm{SiO}_{2} \cdot 2 \mathrm{H}_{2} \mathrm{O}\right)$ has been identified as one of the most efficient sorbents for sequestration of potassium [9-16]. It is decomposed at temperatures of $450-600^{\circ} \mathrm{C}$ by releasing water and forming an amorphous mixture of alumina and silica called metakaolinite [10]. It suppresses the release of potassium from biomass [11] and removes gaseous potassium species at fluidised bed combustion temperatures [10] in both oxidising and reducing atmospheres [12]. Kaolin reacts with potassium-containing species to form both amorphous and crystalline phases. Reactions 2 and 3 describes the formation of kalsilite $\left(\mathrm{KAlSiO}_{4}\right)$ and leucite $\left(\mathrm{KAlSiO}_{6}\right)$ which have been found as products from reactions between kaolin and straw ash [13].

$\mathrm{Al}_{2} \mathrm{O}_{3} \cdot 2 \mathrm{SiO}_{2} \cdot 2 \mathrm{H}_{2} \mathrm{O}+2 \mathrm{KCl} \rightarrow 2 \mathrm{KAlSiO}_{4}+\mathrm{H}_{2} \mathrm{O}+2 \mathrm{HCl}$

$\mathrm{Al}_{2} \mathrm{O}_{3} \cdot 2 \mathrm{SiO}_{2} \cdot 2 \mathrm{H}_{2} \mathrm{O}+2 \mathrm{SiO}_{2}+2 \mathrm{KCl} \rightarrow 2 \mathrm{KAlSiO}_{6}+\mathrm{H}_{2} \mathrm{O}+2 \mathrm{HCl}$

Aluminium containing additives contributes to sequestrate potassium by formation not only of potassium aluminium silicates but also of potassium aluminium oxides and other potassium aluminium compounds [14]. Other materials containing the protective elements aluminium and silica, or sulphur can be used as additives [16-18]. However, formation of alkali alumino silicates appears to be the main alkali sequestration path, dominating over sulphation $[17,18]$.

Potassium can also be captured in ash by formation of phosphates $[15,24]$. Mono calcium phosphate $\left(\mathrm{Ca}\left(\mathrm{H}_{2} \mathrm{PO}_{4}\right)\right)$ has been found to bind potassium during combustion of straw [15]. Furthermore, crystalline phases containing potassium and phosphorus have been identified in ash from combustion of cereal grains. The dominating phases found were $\mathrm{CaK}_{2} \mathrm{P}_{2} \mathrm{O}_{7}$ and $\mathrm{MgKPO}_{4}$. Increased amounts of lime shifted the ash composition to calcium rich potassium phosphates such as $\mathrm{CaKPO}_{4}, \mathrm{Ca}_{10} \mathrm{~K}\left(\mathrm{PO}_{4}\right)_{7}$ and $\mathrm{Ca}_{5}\left(\mathrm{PO}_{4}\right)_{3}(\mathrm{OH})[24]$.

\section{Methods and materials}

\subsection{Research boiler and operating conditions}

The combustion tests were performed in a $12 \mathrm{MW}_{\text {th }}$ circulating fluidised bed boiler. The boiler is built for research purpose but has all the characteristics of a small commercial unit producing heat. Fig. 1 shows a schematic picture of the facility. The combustion chamber (1) has a cross section of $2.25 \mathrm{~m}^{2}$ and a height of $13.6 \mathrm{~m}$. The various fuels are fed at the bottom of the bed through fuel chutes (2). The circulating material is separated at the primary cyclone (3) and returned to the combustion chamber through the cyclone leg (4) and particle seal (5). An external heat exchanger (6) cools the circulating material before re-entering the combustion chamber in case it is required. Municipal sewage sludge was fed by a rebuilt cement pump (7) to the bottom of the bed. Primary air is introduced in the bottom of the bed and secondary air $2.2 \mathrm{~m}$ above the bottom plate. The exhaust gas is cooled to $150^{\circ} \mathrm{C}$ in the convection pass and the fly ashes are separated in the secondary cyclone (8) and the textile filter (9). Kaolin and zeolites were fed at the same position as the sludge. Ammonium sulphate was supplied to the cyclone inlet (10) and hydrated lime to the flue gas pass upstream of the bag filter (11). PVC was added to the return leg from the particle seal. The operating conditions applied were typical for a CFB boiler in commercial operation and found in Table 1.

\subsection{Measurement equipment}

The flue gas composition was obtained by conventional instrumentation and a FTIR (Fourier Transform Infra Red spectrometry) instrument at three locations: up- (12) and downstream (13) of the convection pass and in the stack (14). Measurements of alkali chlorides were performed upstream of the convection pass (12) by an IACM (in-situ alkali chloride monitor) instrument. This instrument is described in detail by Kassman et al. [25]. At the same position (12), an air-cooled probe equipped with deposit rings was inserted into the flue gas channel. In order to simulate a superheater tube, it was maintained at a constant temperature of $500^{\circ} \mathrm{C}$ during $4 \mathrm{~h}$ of exposure to flue gases of $825^{\circ} \mathrm{C}$. The sample rings were weighed before and after exposure to the flue gas to determine the deposit formation rates. 


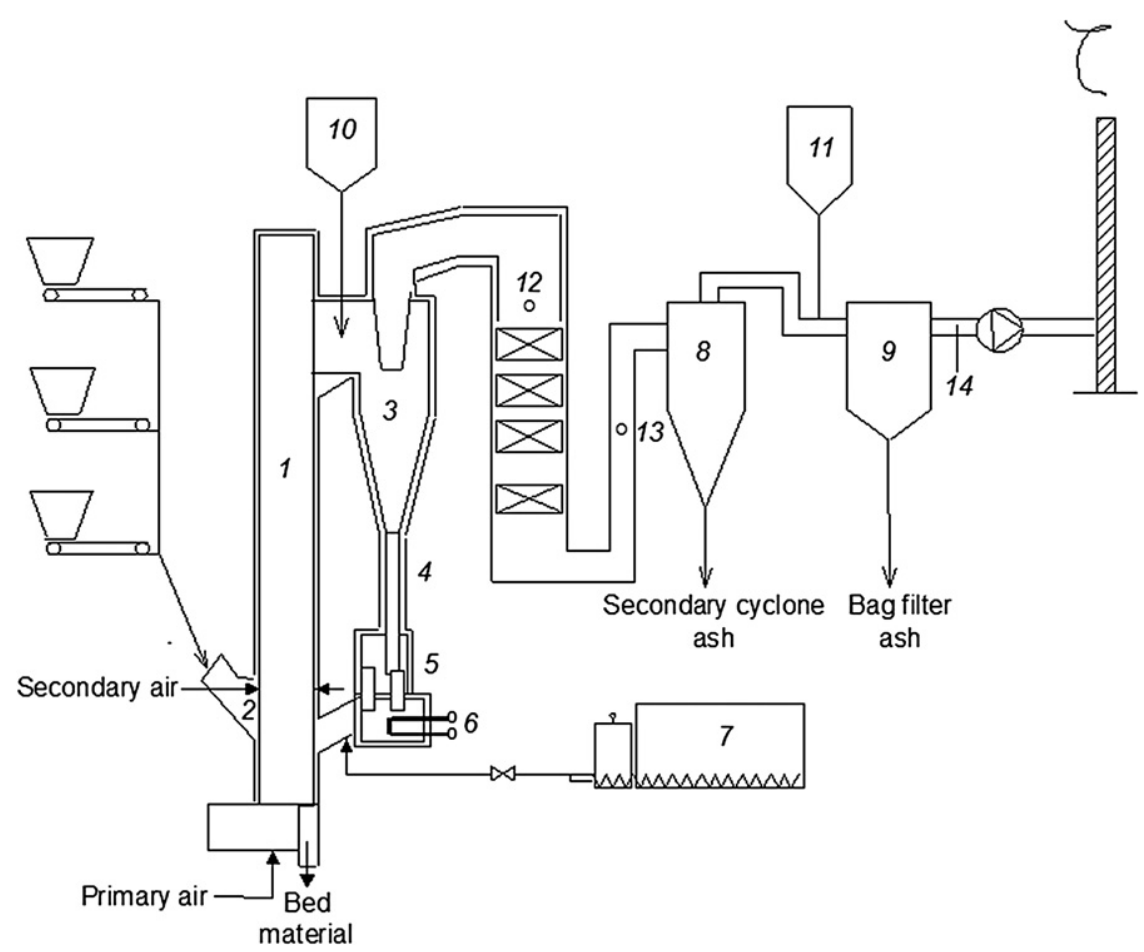

Fig. 1 - Schematic figure of the $12 \mathrm{MW}_{\text {th }}$ circulation fluidised bed boiler.

\subsection{Experimental procedure}

The combustion tests lasted for about $12 \mathrm{~h}$ to attain stable conditions in operation and ash flows. Three combustion strategies were employed: addition of municipal sewage sludge (MSS), addition of zeolites $\left(\left(\mathrm{Na}_{2} \mathrm{CaO}\right) \cdot \mathrm{Al}_{2} \mathrm{O}_{3} \cdot 2 \mathrm{SiO}_{2} \cdot 4 \mathrm{H}_{2} \mathrm{O}\right)$, and addition of ammonium sulphates (AS) together with kaolin (K). Addition of polyvinyl chloride (PVC) was applied in three tests to augment any effects from the additives. In these tests hydrated lime was added ahead of the bag filter to capture $\mathrm{HCl}$ and $\mathrm{SO}_{2}$. Table 2 shows the experimental matrix and Table 3 the input of certain elements and molar ratios during stable conditions.

Fuel samples were taken from the input streams of wood, straw and sludge. Ash samples were taken from the bottom of the furnace at a temperature of $850^{\circ} \mathrm{C}$ and from the secondary cyclone and the bag filter at a temperature of $150^{\circ} \mathrm{C}$. Content of moisture, combustibles and ash in the fuels were determined by a MAC 400 proximate analyzer $785-700$ system. The solid samples collected in each test of fuels, ashes and deposits were sent to an accredited laboratory for analysis. Complementary

\section{Table 1 - Average operating data during the tests.}

\begin{tabular}{llll} 
& Unit & Average & S-dev \\
\hline Load & $\mathrm{MW}_{\text {th }}$ & 6.3 & 0.21 \\
Bed temperature (bottom) & ${ }^{\circ} \mathrm{C}$ & 851 & 1 \\
Bed temperature (top) & ${ }^{\circ} \mathrm{C}$ & 867 & 2 \\
Temperature after primary cyclone & ${ }^{\circ} \mathrm{C}$ & 814 & 8 \\
Temperature after bag filter & ${ }^{\circ} \mathrm{C}$ & 152 & 1 \\
Total riser pressure drop & $\mathrm{kPa}$ & 7.0 & 0.69 \\
Excess air ratio & & 1.24 & 0.04 \\
Primary air flow devided by total air flow & $\%$ & 56 & 1 \\
Superficial velocity at the top of riser & $\mathrm{ms}^{-1}$ & 4.8 & 0.13 \\
\hline
\end{tabular}

SEM EDX (scanning electron microscopy electron dispersive Xray) and XRD (X-ray powder diffraction) analyses were performed on deposits and secondary cyclone ashes. The instruments used in these analyses were a Hitachi N5000 and a Siemens D5000 powder diffractometer. The diffraction results were compared with standards in the JCPDS diffraction database for identification of crystalline ash components.

\subsection{Fuel composition}

Table 4 shows the composition of the fuels. The wood pellets were produced from stem wood of mixed hardwoods such as birch, maple and aspen originating from the Baltic countries. The straw pellets were made of winter wheat originating from Sealand, Denmark. The sludge used was a mechanically dewatered municipal sewage sludge produced in the second largest wastewater treatment plant in Sweden which takes care of wastewater from 775000 inhabitants of the city of

\section{Table 2 - Experimental matrix.}

\begin{tabular}{ll} 
Test & \\
\hline RT & $\begin{array}{l}\text { Reference test. Combustion of wood and } \\
\text { straw pellets. } \\
\text { Addition of municipal sewage sludge to the } \\
\text { reference test. } \\
\text { Addition of Zeolites to the reference test. }\end{array}$ \\
Zeolites & $\begin{array}{l}\text { Addition of PVC to the reference test. } \\
\text { Addition of PVC and municipal sewage sludge } \\
\text { to the reference test. } \\
\text { PVC }\end{array}$ \\
PVC + MSS \\
PVC + AS + K the reference test.
\end{tabular}


Table 3 - Input of certain elements and molar ratios.

\begin{tabular}{|c|c|c|c|c|c|c|c|c|c|}
\hline Test & Alkali & $\mathrm{Al}$ & $\mathrm{Cl}$ & $\mathrm{S}$ & Kaolin & Zeolites & $\mathrm{Cl}(\mathrm{K}+\mathrm{Na})^{-1}$ & $\mathrm{~S} \mathrm{Cl}^{-1}$ & $\mathrm{Al}(\mathrm{K}+\mathrm{Na})^{-1}$ \\
\hline Unit & $\left(\mathrm{mole}^{-1}\right)^{\mathrm{a}}$ & $\left(\mathrm{mole} \mathrm{h}^{-1}\right)$ & $\left(\mathrm{mole} \mathrm{h}^{-1}\right)$ & $\left(\right.$ mole $\left.\mathrm{h}^{-1}\right)$ & $\left(\mathrm{kgh}^{-1}\right)^{\mathrm{b}}$ & $\left(\mathrm{kg} \mathrm{h}^{-1}\right)^{\mathrm{c}}$ & - & - & - \\
\hline RT & 98 & 3.0 & 33 & 12 & & & 0.34 & 0.38 & 0.03 \\
\hline MSS & 143 & 265 & 33 & 41 & & & 0.23 & 1.25 & 1.85 \\
\hline Zeolites & 99 & 275 & 33 & 12 & & 39 & 0.33 & 0.38 & 2.78 \\
\hline PVC & 86 & 3.0 & 66 & 11 & & & 0.77 & 0.17 & 0.03 \\
\hline PVC + MSS & 144 & 280 & 69 & 41 & & & 0.48 & 0.61 & 1.94 \\
\hline $\mathrm{PVC}+\mathrm{AS}+\mathrm{K}$ & 96 & 100 & 64 & 161 & 13 & & 0.67 & 2.50 & 1.04 \\
\hline
\end{tabular}

a $\mathrm{K}+\mathrm{Na}$ (between 90 and $95 \%$ of the alkali is potassium).

b Molar weight kaolin $238.1 \mathrm{~kg} \mathrm{kmol}^{-1}\left(\mathrm{Al}_{2} \mathrm{Si}_{2} \mathrm{O}_{5}(\mathrm{OH})_{4}\right)$.

c Molar weight zeolites $284.0 \mathrm{~kg} \mathrm{kmol}^{-1}\left(\left(\mathrm{Na}_{2} \mathrm{O}\right)\left(\mathrm{Al}_{2} \mathrm{O}_{3}\right)\left(\mathrm{SiO}_{2}\right)\right)$.

Göteborg and its surroundings. The mixes of wood and straw pellets were in average composed of $75 \%$ wood pellets and $25 \%$ straw pellets based on mass of dry fuel. The share of straw was estimated to generate a sufficiently problematic fuel to form deposits but to avoid bed agglomeration during the experiments. The fuel mixture in the tests with municipal sewage sludge was in average composed of $55 \%$ wood pellets, $21 \%$ straw pellets and $24 \%$ sludge based on mass of dry fuel.

\section{Results}

\subsection{Flow of ash components, chlorine and sulphur to the boiler}

Addition of municipal sewage sludge to wood and straw pellets increases the flow of moisture and ash to the boiler.

\section{Table 4 - Average fuel properties.}

\begin{tabular}{|c|c|c|c|c|}
\hline Fuel & Unit & WP & SP & MSS \\
\hline \multicolumn{5}{|l|}{ Proximate analysis } \\
\hline Moisture (as received) & wt.\% & 8.5 & 10.8 & 73.4 \\
\hline Ash (dry) & wt.\% & 0.5 & 7.2 & 52.3 \\
\hline Combustibles (dry) & wt.\% & 99.5 & 92.8 & 47.7 \\
\hline Volatiles $\left(\mathrm{daf}^{\mathrm{a}}\right)$ & wt.\% & 81.9 & 83.2 & 93.2 \\
\hline \multicolumn{5}{|l|}{ Ultimate analysis dafa } \\
\hline $\mathrm{C}$ & wt.\% & 50.5 & 49.3 & 49.5 \\
\hline $\mathrm{H}$ & wt.\% & 6.0 & 6.1 & 7.5 \\
\hline $\mathrm{O}$ & wt.\% & 43.4 & 43.7 & 35.5 \\
\hline $\mathrm{S}$ & wt.\% & 0.01 & 0.08 & 1.71 \\
\hline $\mathrm{N}$ & wt.\% & 0.06 & 0.46 & 5.76 \\
\hline $\mathrm{Cl}$ & wt.\% & 0.02 & 0.27 & 0.13 \\
\hline \multicolumn{5}{|l|}{ Heating value } \\
\hline HHV & $\mathrm{MJkg}^{-1}$ & 18.7 & 16.3 & 2.5 \\
\hline LHV & $\mathrm{MJkg}^{-1}$ & 17.1 & 14.9 & 0.5 \\
\hline \multicolumn{5}{|l|}{ Ash analysis (dry ash) } \\
\hline $\mathrm{Al}$ & $\mathrm{gkg}^{-1}$ & 6.7 & 4.0 & 116 \\
\hline $\mathrm{Ca}$ & $\mathrm{gkg}^{-1}$ & 152 & 72.4 & 37.4 \\
\hline $\mathrm{Fe}$ & $\mathrm{gkg}^{-1}$ & 8.8 & 3.4 & 130 \\
\hline $\mathrm{K}$ & $\mathrm{gkg}^{-1}$ & 138 & 157 & 18.6 \\
\hline $\mathrm{Mg}$ & $\mathrm{gkg}^{-1}$ & 29.8 & 12.2 & 10.6 \\
\hline $\mathrm{Na}$ & $\mathrm{gkg}^{-1}$ & 7.5 & 6.3 & 7.4 \\
\hline $\mathrm{P}$ & $\mathrm{gkg}^{-1}$ & 13.0 & 12.0 & 48.9 \\
\hline $\mathrm{Si}$ & $\mathrm{gkg}^{-1}$ & 116 & 230 & 156 \\
\hline
\end{tabular}

a daf $=$ dry and ash free.
Fig. 2 compares the average flow of main ash components, chlorine, and sulphur with the fuels in the reference test and the test with municipal sewage sludge addition. Sludge conveyed a large amount of aluminium, iron, phosphorus and silica to the boiler. One reason to the increased flow of iron is the use of iron sulphate $\left(\mathrm{Fe}_{2}\left(\mathrm{SO}_{4}\right)_{3}\right)$ as precipitation agent for phosphorus removal in the wastewater treatment plant. The increased amount of aluminium originates partly from so called zeolites [26]. The substance is widely used in detergents as water-softening agent (as a substitute to phosphates) and due to that present in the sludge. It is a crystalline aluminosilicate with defined, uniform lattice and pore structure. The structure consists of $\mathrm{SiO}_{4}$ and $\mathrm{AlO}_{4}$ tetrahedra, it is negatively charged thus attracts cations such as $\mathrm{Na}, \mathrm{K}, \mathrm{Mg}$ and $\mathrm{Ca}$. All ash elements are likely to influence the fate of potassium but zeolites and phosphorus are of special interest since various forms of aluminium silicates and phosphates previously have shown ability to sequestrate potassium during combustion.

\subsection{Flue gas composition during trimming of the sludge flow}

Fig. 3 clearly demonstrates the positive effect from municipal sewage sludge addition to combustion of high alkali biomass.

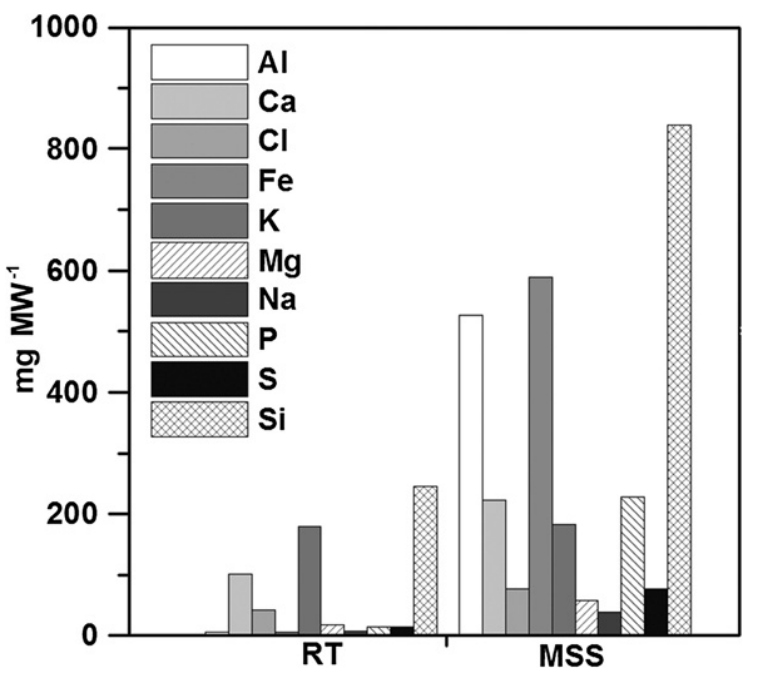

Fig. 2 - Flow of ash components, chlorine and sulphur to the boiler ( $\mathrm{mg} \mathrm{MW}^{-1}$ ). 


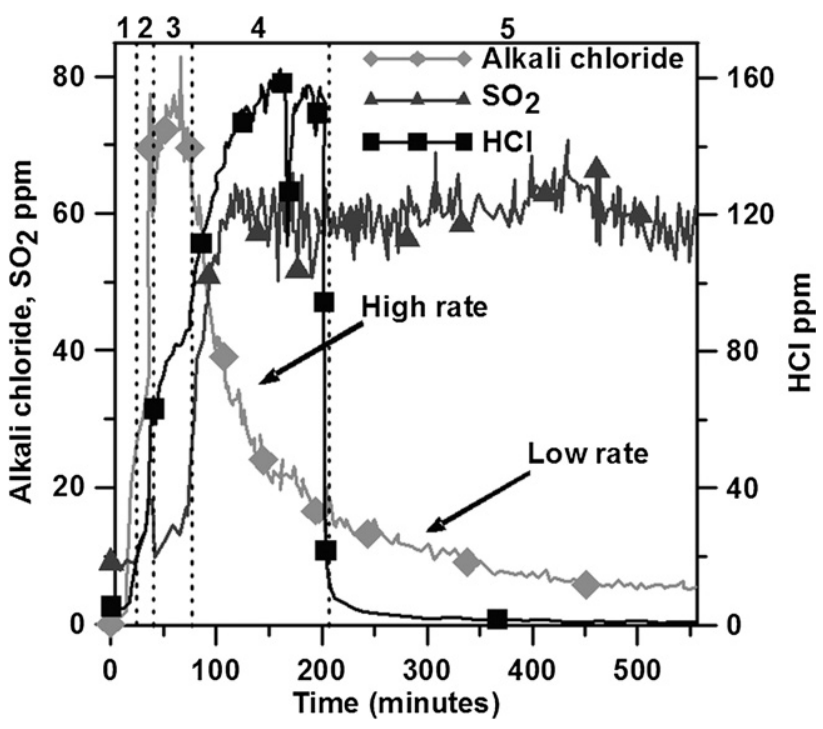

Fig. 3 - Concentrations of alkali chlorides and $\mathrm{SO}_{2}$ upstream of the convection pass, and the $\mathrm{HCl}$ concentration in the stack (ppm as measured).

The figure shows the concentrations of alkali chlorides and $\mathrm{SO}_{2}$ upstream the convection pass, and the $\mathrm{HCl}$ concentration measured in the stack, during $9 \mathrm{~h}$ of test operation. The left axis shows the concentrations of alkali chlorides and $\mathrm{SO}_{2}$, and the right axis shows the concentration of $\mathrm{HCl}$. The figure is divided in 5 sections marked with numbers in the top of the figure and dashed lines to indicate the changes of fuel and additive supply during the test. The amount of alkali chloride detected in the flue gas was mainly potassium chloride since the content of sodium in the fuel was finite. The test started with combustion of pure wood pellets which resulted in an alkali chloride concentration below the limit for problematic operation $(\leq 5 \mathrm{ppm})$ as can be seen in section 1 . Straw pellets were introduced to the boiler at $15 \mathrm{~min}$. The straw increased the amount of available potassium and chlorine thus the concentration of alkali chloride in the combustion chamber which is demonstrated in section 2. PVC was supplied at $35 \mathrm{~min}$ and the excess of chlorine drastically increased the formation of alkali chlorides and $\mathrm{HCl}$. At this stage of the combustion test (3) both alkali chloride and $\mathrm{HCl}$ reached a level of about $75 \mathrm{ppm}$ in the flue gas. Municipal sewage sludge was fed to the boiler after 70 min and caused a clear decrease of the alkali chloride concentration. Simultaneously, the concentration of $\mathrm{HCl}$ and $\mathrm{SO}_{2}$ was increased (4). The response observed can be divided in two steps. The rate of decrease of the alkali chloride concentration was high immediately after the start of the sludge feed. This direct response demonstrates how the increased flow of sulphur with the sludge reacted with alkali and formed alkali sulphates during $\mathrm{HCl}$ release. The $\mathrm{SO}_{2}$ concentration stabilised at an earlier stage than the concentration of alkali chlorides and $\mathrm{HCl}$, which suggests that the sulphur chemistry reached equilibrium before the alkali chemistry. The alkali chloride concentration continued to decrease with a relatively low rate during the complete test. Just before $200 \mathrm{~min}$ hydrated lime was added ahead of the bag filter to capture $\mathrm{HCl}$ which is clearly seen in section 5 .

\subsection{Flue gas composition at stable conditions}

Fig. 4 shows the flue gas concentration in each test at stable operation. Combustion of wood and straw pellets resulted in alkali chloride concentrations of $44 \mathrm{ppm}$ (RT). Addition of municipal sewage sludge decreased the concentration to $0.5 \mathrm{ppm}$ (MSS). Addition of zeolites reduced the concentration as well, though less efficiently compared to sludge.

Addition of PVC (test PVC) increased the concentration of both alkali chlorides and $\mathrm{HCl}$. The composition of the flue gas in test PVC + MSS shows that alkali chloride formation can be controlled with municipal sewage sludge addition even though the fuel is highly contaminated with chlorine. The alkali chloride concentration was reduced from 109 (test PVC) to $5 \mathrm{ppm}$. Addition of ammonium sulphate and kaolin (test $\mathrm{PVC}+\mathrm{AS}+\mathrm{K}$ ) resulted in an alkali chloride concentration of $13 \mathrm{ppm}$. Both sludge addition (test PVC + MSS) and addition of ammonium sulphate and kaolin (test PVC + AS $+\mathrm{K}$ ) caused increased concentration of $\mathrm{HCl}$ in the stack. In these two tests the amount of available sulphur for reaction with alkali chlorides was increased. In the test with zeolite addition the amount of available sulphur was constant and the $\mathrm{SO}_{2}$ and $\mathrm{HCl}$ concentrations in the flue gas were more or less unaffected. Still, the concentration of alkali chloride decreased. The result suggests that alkali chlorides were removed from the flue gas possibly by reaction with aluminium silicates or by adsorption on the increased amount of particles in the flue gas.

\subsection{Deposit formation}

The deposit formation rates, shown in Fig. 5, were clearly reduced in the tests with municipal sewage sludge addition. Zeolite addition caused the opposite effect and increased the

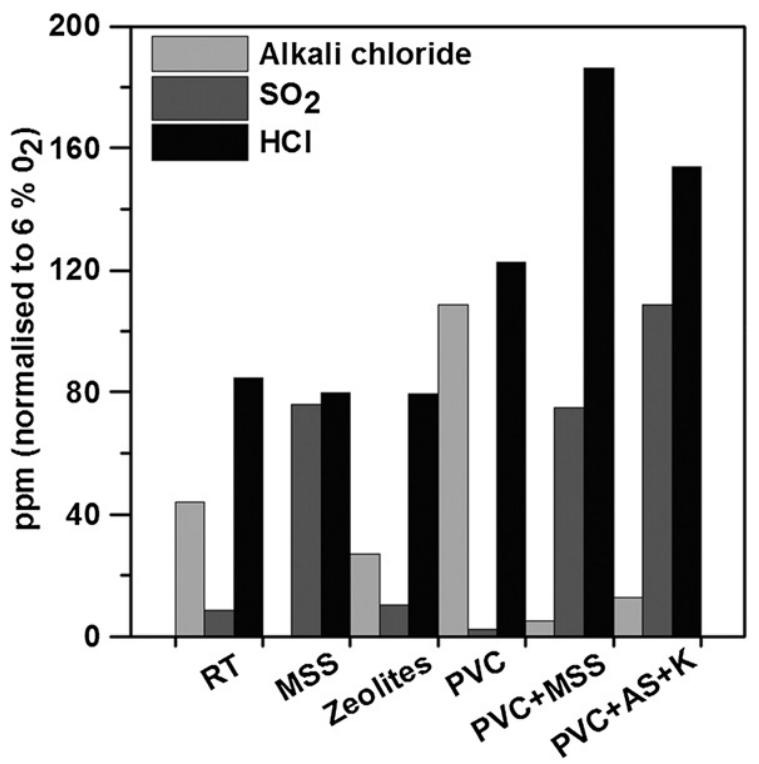

Fig. 4 - Flue gas concentration before the convection pass. 


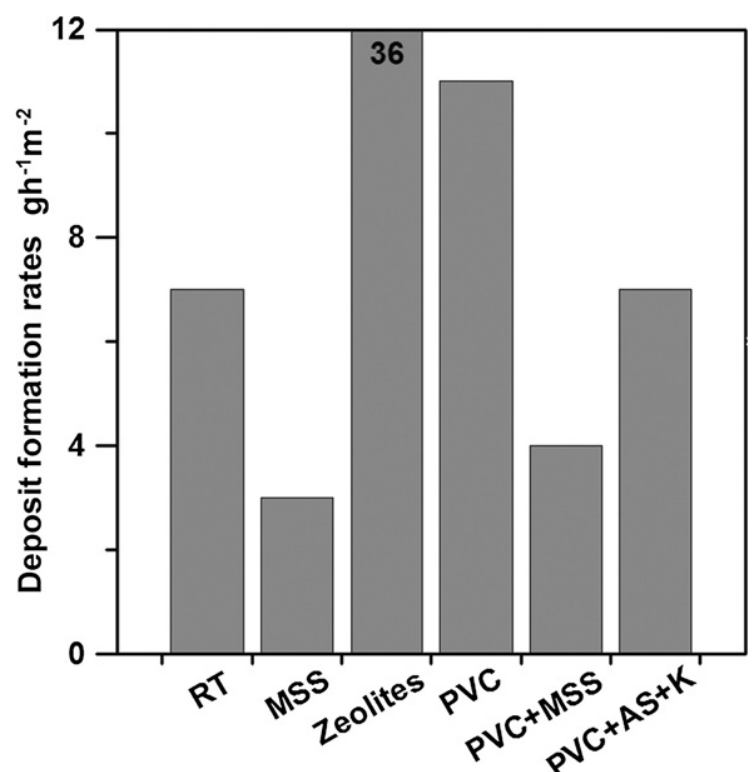

Fig. 5 - Deposit formation rates. The value for Zeolites is $36 \mathrm{gh}^{-1} \mathrm{~m}^{-2}$.

formation rate by several times. The reason was that the fine zeolite particles followed the flue gas and were deposited directly on the sample ring. As expected, addition of PVC increased the formation rate in all tests. Addition of ammonium sulphate and kaolin had a reducing effect, but it was less pronounced compared to sludge addition. Addition of sludge was the most effective additive for preventing deposit formation during combustion of high alkali biomass with both normal and high content of chlorine.

The various additives affected not only the deposit formation rate but also the deposit composition as illustrated in Fig. 6 . The analyses were performed on the windward side of the deposit samples. The deposits from combustion of wood and straw pellets were mainly composed of potassium and chlorine. Addition of municipal sewage sludge eliminated

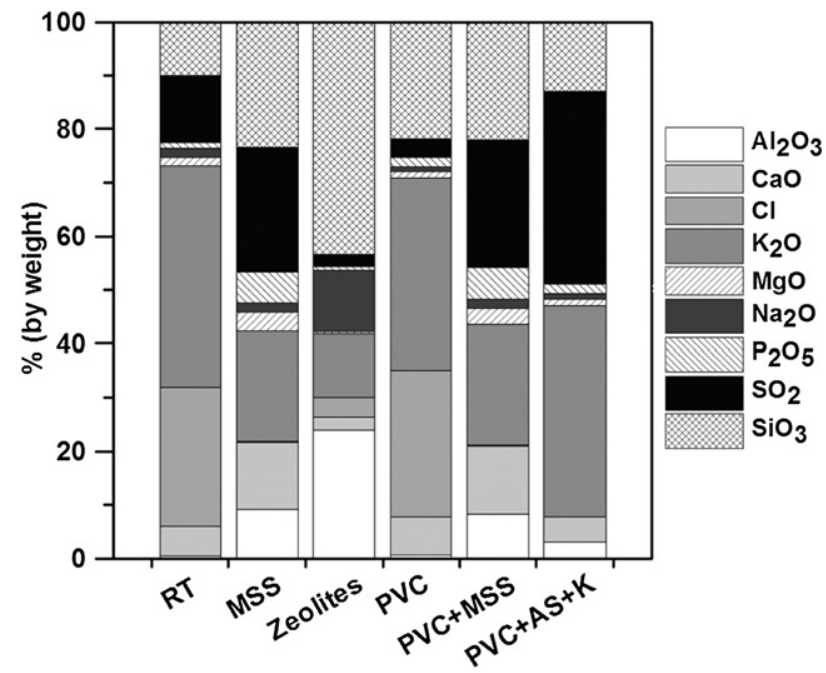

Fig. 6 - Deposit composition on the windward side obtained from SEM EDX analyses. the chlorine content in the deposits, reduced the fraction of potassium and increased the share of aluminium, calcium and sulphur. Addition of zeolites reduced the share of chlorine, potassium, and sulphur and increased the share of aluminium, sodium, and silica. The change reflects directly the chemical composition of the zeolite powder which supports the theory that the additive partly followed the flue gas and deposited on the tubes in the convection section. Addition of PVC decreased the share of sulphur and increased the share of silica in the deposit compared to the reference test. Addition of ammonium sulphate and kaolin increased the share of potassium and sulphur and decreased the share of chlorine in the deposit. Potassium chloride was clearly detected with XRD in the deposit samples from the reference test and the test with addition of PVC only. All additives apart from PVC reduced the amount of $\mathrm{KCl}$ in the deposits below the detection limit of the instrument. Potassium was instead found in sulphates such as $\mathrm{K}_{2} \mathrm{SO}_{4}, \mathrm{~K}_{3} \mathrm{Na}\left(\mathrm{SO}_{4}\right)_{2}$ and $\mathrm{K}_{2} \mathrm{Ca}_{2}\left(\mathrm{SO}_{4}\right)_{3}$.

\subsection{Ash formation}

Table 5 shows the measured ash flows. The data demonstrates clearly how sludge addition increased the total ash flows. It seems further like most of this ash was either remained in the bed or separated in the secondary cyclone. Addition of zeolites increased the flow of both bed and filter ash. The flow of secondary cyclone ash was more or less unchanged in this test. Addition of PVC clearly increased the flow of filter ash, and addition of ammonium sulphate and kaolin seemed to increase all ash flows but most apparently, the flow of filter ash. The high filter ash flow in this test is also due to the PVC addition.

4.5.1. Elemental composition of the secondary cyclone ashes Fig. 7 shows the elemental composition of the secondary cyclone ashes analysed with SEM EDX. The content of $\mathrm{SiO}_{2}$ is excluded from the figure. It reached between 50 and $70 \%$ in the ash samples. The ash from the reference test contained mainly oxygen, silicon, calcium, potassium, magnesium and sulphur. Addition of PVC increased the content of potassium and chlorine. Sludge addition clearly affected the composition and increased the content of aluminium, iron and phosphorus in the ash. The share of potassium was low compared to the ash from tests with other additives. On the other hand, the total amount of secondary cyclone ash increased by more than 5 times due to the addition of sludge. Ash from the test with zeolite addition contained elevated amounts of potassium and some chlorine which indicates that the alkali chlorides, in this case, were not fully eliminated by the zeolites due to the loss of

Table 5 - Ash flows $\left(\mathrm{kgh}^{-1}\right)$.

Bed Secondary cyclone Bag filter Total

\begin{tabular}{lrrrr} 
RT & 12 & 6 & 3 & 21 \\
MSS & 49 & 36 & 5 & 90 \\
Zeolites & 28 & 6 & 13 & 47 \\
PVC & 5 & 5 & 28 & 38 \\
PVC + MSS & 49 & 31 & 62 & 142 \\
PVC + AS + K & 16 & 12 & 58 & 86 \\
\hline
\end{tabular}




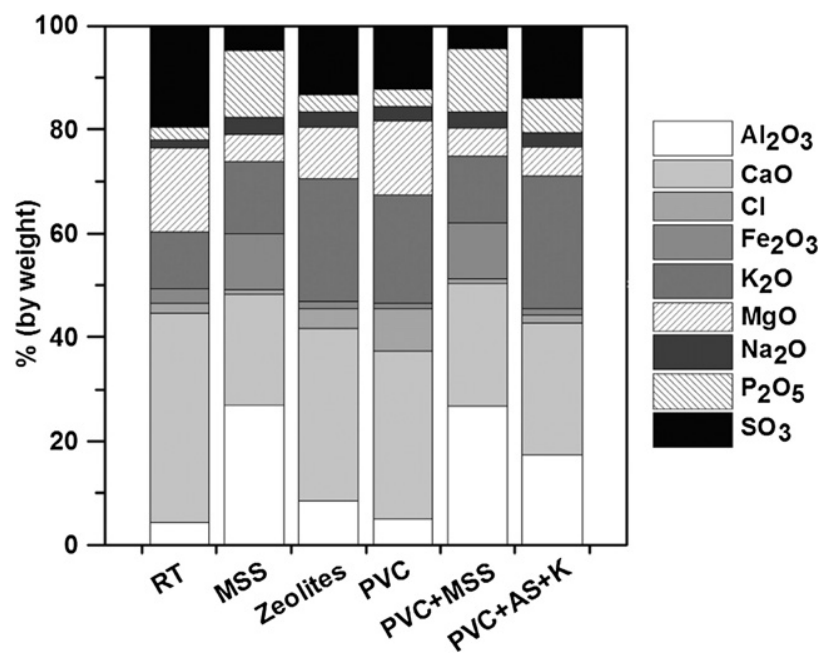

Fig. 7 - Elemental composition of the secondary cyclone ash recalculated without the $\mathrm{SiO}_{2}$.

active none reacted zeolite to the fly ash, fly ash that settled on the heat exchange tubes in the convection section.

\subsubsection{Elemental maps of the secondary cyclone ash in test} MSS

Fig. 8 shows elemental maps of secondary cyclone ash from the test with sludge addition (MSS). A SEM picture of the
Table 6 - Elemental compositions of spot analyses on the secondary cyclone ash from test MSS (weight \%).

\begin{tabular}{lrrrrrrrrr} 
& 1 & 2 & 3 & 4 & 5 & 6 & 7 & 8 & 9 \\
\hline $\mathrm{Al}_{2} \mathrm{O}_{3}$ & 39 & 36 & 45 & 20 & 52 & 20 & 5 & 6 & 7 \\
$\mathrm{CaO}$ & 11 & 14 & 27 & 20 & 5 & 11 & 58 & 28 & 15 \\
$\mathrm{Cl}$ & 0 & 0 & 0 & 0 & 0 & 0 & 0 & 6 & 19 \\
$\mathrm{Fe}_{2} \mathrm{O}_{3}$ & 8 & 13 & 4 & 25 & 4 & 41 & 3 & 1 & 1 \\
$\mathrm{~K}_{2} \mathrm{O}$ & 15 & 16 & 11 & 23 & 15 & 9 & 7 & 10 & 25 \\
$\mathrm{MgO}$ & 3 & 3 & 3 & 21 & 3 & 3 & 4 & 7 & 2 \\
$\mathrm{Na}_{2} \mathrm{O}$ & 3 & 2 & 2 & 1 & 5 & 1 & 1 & 3 & 9 \\
$\mathrm{P}_{2} \mathrm{O}_{5}$ & 20 & 15 & 7 & 8 & 14 & 14 & 19 & 28 & 2 \\
$\mathrm{SO}_{3}$ & 1 & 0 & 0 & 0 & 1 & 2 & 3 & 11 & 21
\end{tabular}

analysed area is found in the upper left corner of the figure. Potassium was clearly correlated with aluminium, iron and phosphorus and possibly also with calcium and magnesium. Corresponding maps over ash from the test with zeolite addition showed that potassium was related to aluminium. The ash also contained distinct particles composed of potassium and chlorine. Aluminium and chlorine were the only elements related to potassium in the test with zeolite addition. Addition of ammonium sulphate and kaolin generated ash particles composed of potassium and aluminium or potassium and sulphur. Potassium was further related to calcium and possibly to magnesium.

The numbers in the SEM picture point out the approximate location of spot analyses and Table 6 shows the chemical
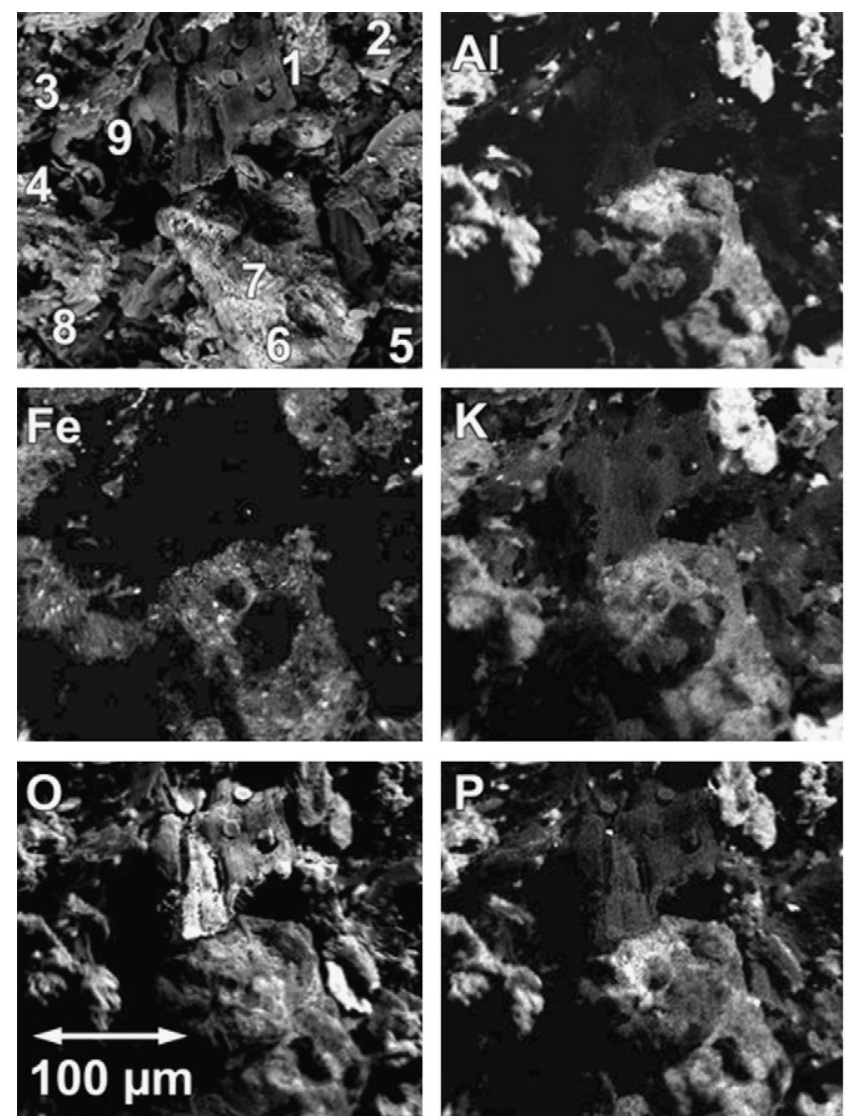
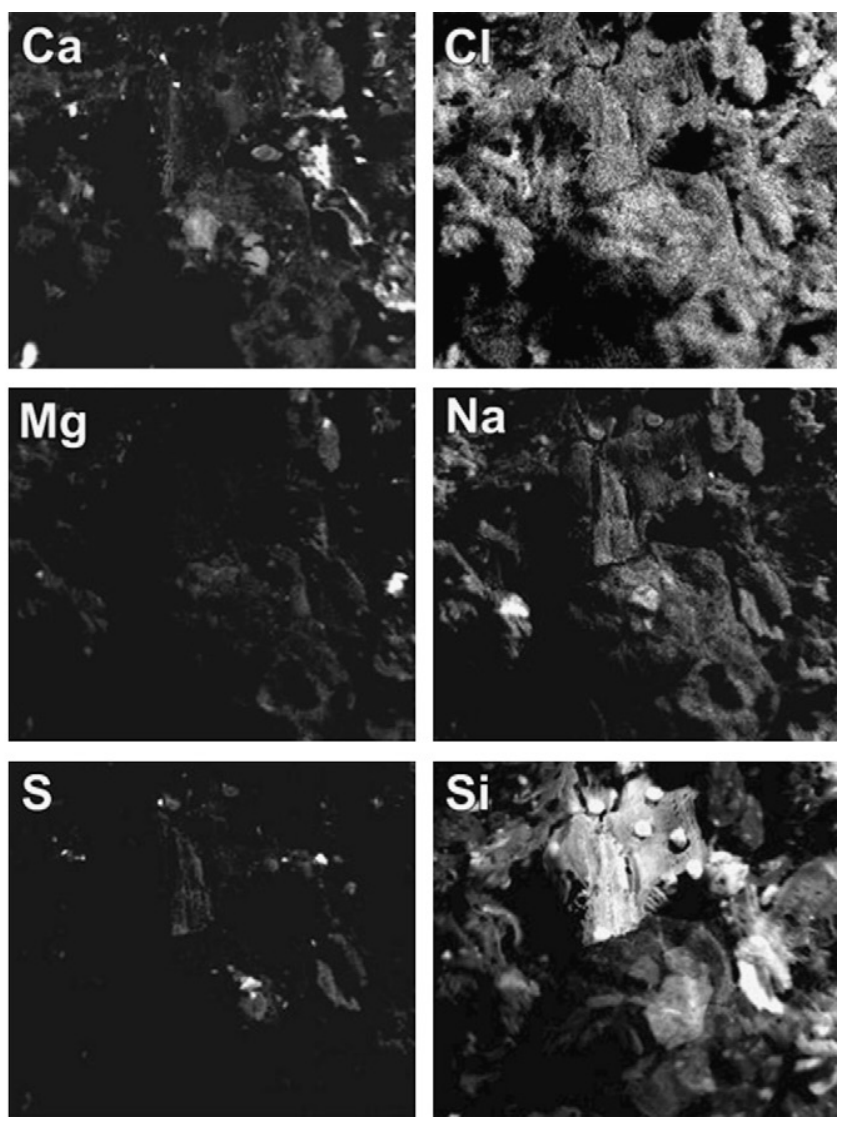

Fig. 8 - Mapping of elements in the secondary cyclone ash in test MSS. 
Table 7 - Crystalline phases containing potassium in the secondary cyclone ashes identified with XRD.

\begin{tabular}{|c|c|c|c|c|c|c|}
\hline & RT & MSS & Zeolites & PVC & $\mathrm{PVC}+\mathrm{MSS}$ & $\mathrm{PVC}+\mathrm{AS}+\mathrm{K}$ \\
\hline $\mathrm{Ca}_{9} \mathrm{MgK}\left(\mathrm{PO}_{4}\right)_{7}$ & & medium & & & medium & \\
\hline $\mathrm{KCa}_{9} \mathrm{Fe}\left(\mathrm{PO}_{4}\right)_{7}$ & & medium & & & medium & \\
\hline $\mathrm{KCl}$ & strong & & weak & strong & & weak \\
\hline $\mathrm{K}_{2} \mathrm{SO}_{4}$ & & weak & & & weak & medium \\
\hline $\mathrm{K}-\mathrm{Ca}-\mathrm{S}$ & medium & & & medium & & \\
\hline $\mathrm{KAlSiO}_{8}$ & & strong & & & strong & \\
\hline $\mathrm{K}-\mathrm{Al}-\mathrm{Si}$ & medium & medium & medium & medium & medium & medium \\
\hline
\end{tabular}

composition in each spot. The content of $\mathrm{SiO}_{2}$ is excluded. Spots rich in potassium contained, in general, also silicon, aluminium, calcium, iron and phosphorus. A mixture of various particles is found in the spot analysis. Spot 1 and 2 are rich in aluminium, potassium and phosphorus and to some degree iron. Both spot 3 and 4 are relatively low in phosphorus. Spot 3 seems to be representing the case where potassium is captured by aluminium silicates, including some calcium, while in spot 4 , the iron content is much higher. Spots 7 and 8 are low in aluminium but high in calcium and phosphorus and fairly low in potassium. Spot 8 and 9 are relatively high in sulphur. The amounts of remaining elements were in general low and close to the accuracy limit of the instrument. The calcium content appeared larger in the spot analyses than in the previous mapping. The spot analyses are in general more correct compared to the mapping since the exposed area is smaller and consequently the information emitted per second to the detector larger. Spot analyses on ash from the test with zeolite addition revealed that potassium aluminium silicates and silicates containing potassium, calcium and sulphates with traces of either magnesium or phosphorus were formed. Similar elemental compositions were obtained in the spot analyses of ash from the test with ammonium sulphate and kaolin addition.

\subsubsection{Crystalline phases containing potassium in the} secondary cyclone ashes

The ashes were composed of crystalline phases but also amorphous material, which caused diffuse diffraction from the poorly crystalline phases, mainly in the area of amorphous silica compounds. In addition, the comparisons with diffraction patterns in the database sometimes indicated more than one possible phase for the same peak. All ashes contained $\mathrm{SiO}_{2}$. Ash from the reference test contained $\mathrm{KCl}$, potassium aluminium silicates and potassium calcium sulphates. The effect of PVC addition was marginal. The only clear difference observed in the diffraction pattern was the stronger peaks for $\mathrm{KCl}$. All additives reduced the peaks for $\mathrm{KCl}$ in the ash. In the tests with addition of zeolites, and addition of ammonium sulphate and kaolin, the peaks for $\mathrm{KCl}$ were weak but could be distinguished. Corresponding peaks for $\mathrm{KCl}$ were absent in the diffraction pattern obtained from the sludge ash. Various aluminium silicates were found in the ash from the test with zeolite addition. It was further indicated that some of these aluminium silicates contained potassium but also sodium, and calcium. In the test with ammonium sulphate and kaolin addition, the main potassium species found were potassium aluminium silicates and $\mathrm{K}_{2} \mathrm{SO}_{4}$. In ash from tests with sludge, potassium was found in aluminium silicates, sulphates, and phosphates. The phosphates contained calcium and various amounts of iron, potassium and magnesium, possibly in the form of $\mathrm{Ca}_{9} \mathrm{Fe}\left(\mathrm{PO}_{4}\right)_{7}, \mathrm{Ca} 9 \mathrm{MgK}$ $\left(\mathrm{PO}_{4}\right)_{7}$, and $\mathrm{Ca}_{9} \mathrm{MgK}\left(\mathrm{PO}_{4}\right)_{7}$. The exact components of the phase consisting of aluminium, iron, phosphorus, potassium and silica in the sludge ash, previously detected with SEM EDX, could not be detected with XRD. These components may be amorphous. Table 7 summarises the crystalline phases that contained potassium.

\section{Conclusions}

Formation of corrosive deposits on heat transfer surfaces in the convection pass during combustion of high alkali biomass can be controlled by addition of municipal sewage sludge even though the fuel is highly contaminated with chlorine. Cofiring of municipal sewage sludge decreases the $\mathrm{KCl}$ concentration in the flue gas, thus restricts the deposit formation rate. Furthermore, addition of municipal sewage sludge eliminates the content of chlorine and decreases the content of potassium in the deposits.

The concentration of $\mathrm{KCl}$ in the flue gas is partly limited by sulphation of potassium, partly by potassium sequestration by the sludge ash. The ash is composed of both crystalline and amorphous phases and potassium is present in species mainly composed of silica, aluminium, calcium, iron and phosphorus. The share of each element varies. The test with zeolite addition alone shows that the synthesised aluminium silicates contribute to sequestrate potassium by formation of potassium aluminium silicates, without interference from sulphur, phosphorus and iron. Presence of zeolites decreases the $\mathrm{KCl}$ concentration in the flue gas whereas the $\mathrm{HCl}$ and $\mathrm{SO}_{2}$ concentration is constant. The content of potassium aluminium silicates in the ash indicates that potassium reacts with the added amount of aluminium silicates.

However, zeolites are not the only answer to the posted research question. The content of calcium, iron and phosphorus in the sludge is of importance as well since they all are involved in the potassium chemistry in the ash.

\section{Acknowledgement}

Main support for this work was provided by the Swedish Energy Administration. The large scale tests were performed 
as part of contract no. A06-621 from VärmeForsk Service AB which is gratefully acknowledged. Vattenfall Power Consultant supplied the IACM instrument. The SEM EDX and XRD analyses of deposits and secondary cyclone ashes were performed by grants partly from SWECO AB, partly from Civilingenjörsförbundet. Britt-Marie Steenari is gratefully acknowledged for valuable support and fruitful discussion on the ash chemistry. Further, the authors acknowledge Akademiska Hus $A B$ for maintaining and operating the boiler and the research staff employed by Chalmers University of Technology for carrying out the combustion tests.

\section{R E F E R E N C E S}

[1] Nussbaumer T. Combustion and co-combustion of biomass: fundamentals, technologies, and primary measures for emission reduction. Energy Fuels 2003;17:1510-21.

[2] Frandsen FJ. Utilizing biomass and waste for power production-a decade of contribution to the understanding, interpretation and analysis of deposits and corrosion products. Fuel 2005;84:1277-94.

[3] Miles TR, Baxter LL, Bryers RW, Jenkins BM, Oden LL. Boiler deposits from firing biomass fuels. Biomass and Bioenergy 1996;10:125-38.

[4] Ergudenler A, Ghaly AE. Agglomeration of silica sand in a fluidized bed gasifier operating on wheat straw. Biomass and Bioenergy 1993;4:135-47.

[5] Dayton DC, French RJ, Milne TA. Direct observation of alkali vapor release during biomass combustion and gasification. 1. application of molecular beam/mass spectrometry to switchgrass combustion. Energy Fuels 1995;9:855-65.

[6] Jensen PA, Frandsen FJ, Dam-Johansen K, Sander B. Experimental investigation of the transformation and release to gas phase of potassium and chlorine during straw pyrolysis. Energy Fuels 2000;14(6):1280-5.

[7] Knudsen JN, Jensen PA, Dam-Johansen K. Transformation and release to the gas phase of $\mathrm{Cl}, \mathrm{K}$ and $\mathrm{S}$ during combustion of annual biomass. Energy Fuels 2004;18:1385-99.

[8] Iisa K, Lu Y. Sulfation of potassium chloride at combustion conditions. Energy Fuels 1999;13:1184-90.

[9] Davidsson K, Eskilsson D, Gyllenhammar M, Herstad Svärd S, Kassman H, Steenari B-M, et al. Measures for simultaneous minimisation of alkali related operating problems. Stockholm: Värmeforsk Service AB; 2006.

[10] Tran K-Q, Iisa K, Steenari B-M, Lindqvist O. A kinetic study of gaseous alkali capture by kaolin in the fixed bed reactor equipped with an alkali detector. Fuel 2005;84:169-75.
[11] Tran $\mathrm{K}-\mathrm{Q}$ Iisa $\mathrm{K}$, Hagström M, Steenari B-M, Lindqvist O, Pettersson JBC. On the application of surface ionization detector for the study of alkali capture by kaolin in a fixed bed reactor. Fuel 2004;83:807-12.

[12] Tran K-Q Steenari B-M, Iisa K, Lindqvist O. Capture of potassium and cadmium by kaolin in oxidizing and reducing atmospheres. Energy Fuels 2004;18:1870-6.

[13] Steenari BM, Lindqvist O. High-temperature reactions of straw ash and the anti-sintering additives kaolin and dolomite. Biomass and Bioenergy 1998;14:67-76.

[14] Coda B, Aho M, Berger R, Heing KRG. Behavior of chlorine and enrichment of risky elements in bubbling fluidized bed combustion of biomass and waste assisted by additives. Energy Fuels 2001;15:680-90.

[15] Zeuthen JH, Jensen PA, Jensen JP, Livbjerg H. Aerosol formation during the combustion of straw with addition of sorbents. Energy Fuels 2007;21:699-709.

[16] Aho M. Reduction of chlorine deposition in FB boilers with aluminium-containing additives. Fuel 2001;80:1943-51.

[17] Aho M, Silvennoinen J. Preventing chlorine deposition on heat transfer surfaces with aluminium-silicon rich biomass residue and additive. Fuel 2004;83:1299-305.

[18] Aho M, Ferrer E. Importance of coal ash composition in protecting the boiler against chlorine deposition during combustion of chlorine-rich biomass. Fuel 2005;84:201-12.

[19] Åmand L-E, Leckner Bo, Eskilsson D, Tullin C. Deposits on heat transfer tubes during co-combustion of biofuels and sewage sludge. Fuel 2006;85:1313-22.

[20] Davidsson KO, Åmand L-E, Elled A-L, Leckner B. Effect of cofiring coal and biofuel with sewage sludge on alkali problems in a circulating fluidized bed boiler. Energy Fuels 2007;21:3180-8.

[21] Zevenhoven-Onderwater M, Blomqvist J-P, Skrifvars B-J, Backman R, Hupa M. The prediction of ashes from five different solid fuels in fluidised bed combustion. Fuel 2000; 79:1353-61.

[22] Glarborg P, Marshall P. Mechanism and modelling of the formation of gaseous alkali sulfates. Combustion and Flame 2005;141:22-39.

[23] Jimenez S, Ballester J. Formation of alkali sulphate aerosols in biomass combustion. Fuel 2007;86:486-93.

[24] Lindström E, Sandström M, Boström D, Öhman M. Slagging characteristics during combustion of cereal grains rich in phosphorus. Energy Fuels 2007;21:710-7.

[25] Kassman H, Andersson C, Höglund J, Åmand L-E, Davidsson $\mathrm{K}$. Gas phase alkali chlorides and deposits during cocombustion of coal and biomass, the 19th conference on fluidised bed combustion, Vienna; 2006.

[26] Kurzendörfer CP, Kuhm P, Steber J. Zeolites in the environment. In: Schwuger MJ, editor. Detergents in the environment. New York: Marcel Decker; 1997. p. 127-93. 